\title{
Stimulation of $2^{\prime}, 5^{\prime}$-oligoadenylate synthetase activity in
} sheep endometrium during pregnancy, by intrauterine infusion of ovine trophoblast protein-1, and by intramuscular administration of recombinant bovine interferon- $\alpha_{I} 1$

\author{
M. A. Mirando ${ }^{1, *}$, E. C. Short, $\mathrm{Jr}^{2}$, R. D. Geisert ${ }^{3}$, J. L. Vallet ${ }^{1} \uparrow$ and \\ F. W. Bazer ${ }^{1} \dagger$ \\ ${ }^{1}$ Animal Science Department, University of Florida, Gainesville, Florida 32611, USA and \\ Departments of ${ }^{2}$ Physiological Sciences and ${ }^{3}$ Animal Science, Oklahoma State University, \\ Stillwater, OK 74078, USA
}

\begin{abstract}
Summary. In Expt 1, activity of $2^{\prime}, 5^{\prime}$-oligoadenylate $\left(2^{\prime}, 5^{\prime}\right.$-A) synthetase in endometrium collected on Day 16 (oestrus is Day 0) from the uterine horn ipsilateral to the corpus luteum was greater $(P<0.001)$ for pregnant $(135.5 \pm 1.72 \mathrm{nmol} / \mathrm{mg}$ protein $/ \mathrm{h})$ than for cyclic ewes $(58.5 \pm 0.99 \mathrm{nmol} / \mathrm{mg}$ protein $/ \mathrm{h})$. In pregnant ewes, activity of $2^{\prime}, 5^{\prime}$-A synthetase in endometrium collected from the contralateral uterine horn $(119.5 \pm 1.72 \mathrm{nmol} / \mathrm{mg}$ protein/h) did not differ from that of the ipsilateral horn. In Expt 2, three ovariectomized ewes were treated with progesterone for 10 days and then with oestrogen for 2 days. Activity of $2^{\prime}, 5^{\prime}$-A synthetase on Day 13 was $18 \%$ greater $(P<0 \cdot 10)$ in endometrium collected from the uterine horn receiving infusions of $30 \mu \mathrm{g}$ ovine trophoblast protein-1 (oTP-1) twice a day on Days 10,11 and $12(57 \cdot 7 \pm 0.22 \mathrm{nmol} / \mathrm{mg}$ protein $/ \mathrm{h})$ than from the uterine horn receiving control infusions of serum protein $(S P ; 48.8 \pm 0.22 \mathrm{nmol} / \mathrm{mg}$ protein/h). In Expt 3, activity of 2', $5^{\prime}$-A synthetase on Day 15 was not significantly greater in endometrium collected from the uterine horn of cyclic ewes receiving infusions of $30 \mu \mathrm{g}$ oTP-1 twice a day on Days 12,13 and $14(46.5 \pm 0.37 \mathrm{nmol} / \mathrm{mg}$ protein/h) than in endometrium from the uterine horn receiving infusions of SP $(38.2 \pm 0.37 \mathrm{nmol} / \mathrm{mg}$ protein/h). When results of Expt 2 and Expt 3 were combined, intrauterine infusion of oTP-1 increased $(P<0 \cdot 05)$ activity of $2^{\prime}, 5^{\prime}$-A synthetase in endometrium by $20 \%$. In Expt 4 , activity of 2',5'-A synthetase in endometrium collected from cyclic ewes on Day 16 was increased $(P<0.001)$ by i.m. injection of $1 \mathrm{mg}$ recombinant bovine interferon- $\alpha_{1} 1$ twice a day on Days 12, 13, 14 and $15(993.8 \pm 85.9 \mathrm{nmol} / \mathrm{mg}$ protein $/ \mathrm{h})$ compared with endometrium from ewes similarly treated with placebo $(162 \cdot 1 \pm 85 \cdot 9 \mathrm{nmol} / \mathrm{mg}$ protein $/ \mathrm{h})$.

These results indicate that activity of $2^{\prime}, 5^{\prime}$-A synthetase in endometrium of ewes was increased during early pregnancy, probably by the action of the antiluteolytic conceptus interferon oTP-1. Ewes treated with recombinant bovine interferon- $\alpha_{1} 1$ also had increased endometrial $2^{\prime}, 5^{\prime}$-A synthetase activity, indicating that systemic administration of this interferon may directly affect the uterus and enhance fertility rate in ewes.
\end{abstract}

Keywords: pregnancy; endometrium; 2',5'-oligoadenylate synthetase; ovine trophoblast protein-1; interferon; sheep

\section{Introduction}

Ovine trophoblast protein-1 (oTP-1) and bovine trophoblast protein-1 (bTP-1), major polypeptides secreted by peri-implantation conceptuses, are involved in establishment of pregnancy

*Present address: Department of Animal Sciences, Washington State University, Pullman, WA 99164-6332, USA. $\dagger$ Present address: Roman L. Hruska Meat Animal Research Center, Clay Center, NE, USA. $\ddagger$ Reprint requests. 
(Martal et al., 1979; for review see Bazer et al., 1989, 1991; Thatcher et al., 1989, 1990). These proteins have a high degree of amino acid sequence homology with interferons of the $\alpha_{\text {II }}$ subclass (Imakawa et al., 1987, 1989; Stewart et al., 1987, 1989; Charpigny et al., 1988; Charlier et al., 1989); oTP-1 and bTP-1 have potent antiviral activity (Martal et al., 1988; Pontzer et al., 1988; Lifsey et al., 1989; Roberts et al., 1989; Plante et al., 1990; Short et al., 1991) and oTP-1 possesses immunosuppressive (Newton et al., 1989; Fillion et al., 1991) and antiproliferative (Roberts et al., 1989) biological activities characteristic of interferons.

Preparations of bovine conceptus secretory proteins enriched in bTP-1 stimulate cellular $2^{\prime}, 5^{\prime}$ oligoadenylate $\left(2^{\prime}, 5^{\prime}-\mathrm{A}\right)$ synthetase activity in vitro (Short et al., 1991). The activity of $2^{\prime}, 5^{\prime}-\mathrm{A}$ synthetase is also greater in endometrium of cows during early pregnancy when conceptus bTP-1 secretion is high (Short et al., 1991). Cellular activity of $2^{\prime}, 5^{\prime}$-A synthetase is stimulated by interferons which catalyse increased production of $2^{\prime}, 5^{\prime}$-A which, in turn, activates a $2^{\prime}, 5^{\prime}$-A-dependent endoribonuclease. The $2^{\prime}, 5^{\prime}$-A-dependent endoribonuclease cleaves both viral and cellular RNAs, thereby inhibiting protein synthesis and viral replication within the host cell (see Johnston \& Torrence, 1984; Taylor \& Grossberg, 1990). However, it is not known whether the antiluteolytic effects of oTP-1 and bTP-1 involve activation of the 2',5'-A synthetase system.

Systemic administration of recombinant bovine interferon- $\alpha_{1} 1\left(\operatorname{rbIFN}-\alpha_{1} 1\right)$ has been reported to increase fertility in ewes (Davis et al., 1990; Nephew et al., 1990; Schalue-Francis et al., 1991), but the mechanism responsible is not known.

The present experiments were conducted to determine whether endometrial $2^{\prime}, 5^{\prime}-\mathrm{A}$ synthetase activity increases during early pregnancy or after intrauterine infusion of oTP-1 in ewes. The possibility that reported increases in fertility resulting from intramuscular injections of recombinant bovine interferon- $\alpha_{1} 1$ (rbIFN- $\left.\alpha_{1} 1\right)$ may involve direct action on the uterus (i.e. increased activity of $2^{\prime}, 5^{\prime}$-A synthetase) was also examined.

\section{Materials and Methods}

Animals. Ewes primarily of Rambouillet breeding were observed daily for oestrous behaviour using a vasectomized ram; day of onset of oestrus was designated Day 0. Ewes assigned to pregnant status for collection of conceptuses and for Expt 1 were mated to intact rams at detection of oestrus and 10 and $24 \mathrm{~h}$ later. Ewes assigned to cyclic status for Expts 1, 3 and 4 were mated to vasectomized rams at detection of oestrus only. Ewes assigned to Expt 2 were ovariectomized for longer than 30 days. Surgeries were performed with ewes under halothane-induced general anaesthesia (Fincher et al., 1986).

Experiment 1. Endometrium was collected from ten cyclic and six pregnant ewes at ovariectomy-hysterectomy on Day 16 during two different breeding seasons. Pregnancy was confirmed by the presence of an apparently normal conceptus after flushing each uterus with $20 \mathrm{ml}$ MEM. Uteri of cyclic ewes were similarly flushed. Endometrium was collected from the uterine horn ipsilateral to the corpus luteum of cyclic ewes and from the ipsilateral and contralateral uterine horns of pregnant ewes.

Preparation of proteins for Experiments 2 and 3. Pregnant ewes were laparotomized on Day 16 after oestrus and conceptuses were collected by flushing the uterus with $20 \mathrm{ml}$ modified Eagle's minimum essential medium (MEM). Conceptuses were cultured as described by Godkin et al. (1982). After $30 \mathrm{~h}$, medium was collected, pooled and stored at $-20^{\circ} \mathrm{C}$. Medium was thawed and OTP-1 was purified as previously described (Vallet et al., 1988). The concentration of oTP-1 was determined by the method of Lowry et al. (1951), using bovine serum albumin as standard. OTP-1 was then diluted with $0.9 \%(\mathrm{w} / \mathrm{v}) \mathrm{NaCl}$ to an oTP-1 concentration of $30 \mu \mathrm{g} / \mathrm{ml}$ and $1.0 \mathrm{ml}$ aliquants were stored at $-20^{\circ} \mathrm{C}$.

Blood was collected from the jugular vein of a pregnant ewe on Day 16 and allowed to clot at room temperature $(1 \mathrm{~h})$ and then at $4^{\circ} \mathrm{C}$ overnight. Serum was collected, pooled and dialysed and the protein concentration was determined on pooled, dialysed serum. Serum protein (SP) was then diluted with $0.9 \% \mathrm{NaCl}$ to 750 or $1470 \mu \mathrm{g} / \mathrm{ml}$, divided into $2 \cdot 0$ - or $1 \cdot 0-\mathrm{ml}$ aliquants, respectively, and stored at $-20^{\circ} \mathrm{C}$.

Experiment 2. Three ewes, ovariectomized for more than 30 days, received i.m. injections of $50 \mathrm{mg}$ progesterone/ day in $1 \mathrm{ml}$ maize oil for 10 days and then $100 \mu \mathrm{g}$ oestradiol $-17 \beta$ in $2 \mathrm{ml}$ maize oil for 2 days. On Day 8 after initiation of steroid treatment, ewes were laparotomized and catheters were placed into each uterine horn (Vallet $e t$ al., 1988). Each uterine horn was separated with a double ligature placed just above the internal bifurcation. On Days 10,11 and 12 , each ewe received infusions of $30 \mu \mathrm{g}$ oTP- $1(1 \mathrm{ml})$ plus $1470 \mu \mathrm{g} \mathrm{SP}(1 \mathrm{ml})$ twice a day into one uterine horn and $1500 \mu \mathrm{g} \mathrm{SP}(2 \mathrm{ml})$ into the other at 08:00 and 17:00 h. Each infusion of protein contained $50 \mathrm{mg}$ ampicillin and was 
followed by $1 \mathrm{ml} 0.9 \% \mathrm{NaCl}$ to clear the catheter. Endometrium was collected from both uterine horns of each ewe at hysterectomy on Day 13.

Experiment 3. Three cyclic ewes were laparotomized on Day 10, catheters were placed into each uterine horn and uterine horns were separated with ligatures as previously described. On Days 12,13 and 14, each ewe received infusions of $30 \mu \mathrm{g}$ oTP-1 plus $1470 \mu \mathrm{g}$ SP twice a day into one uterine horn and $1500 \mu \mathrm{g}$ SP into the other uterine horn as described for Expt 2. Endometrium was collected from both uterine horns of each ewe at hysterectomy on Day 15.

Experiment 4. Twelve cyclic ewes received i.m. injections of $1 \mathrm{mg}$ rbIFN- $\alpha_{1} 1$ or vehicle placebo, obtained from Ciba Geigy Limited (Basle, Switzerland), twice a day on Days 12, 13, 14 and 15 during two different breeding seasons (three ewes per treatment per season). Endometrium was collected from both uterine horns of each ewe at hysterectomy on Day 16.

Endometrial activity of $2^{\prime}, 5^{\prime}-A$ synthetase. Endometrium collected at hysterectomy was stored at $-70^{\circ} \mathrm{C}$ until assayed for endometrial $2^{\prime}, 5^{\prime}$-A synthetase activity. Endometrial samples were prepared for analysis by adding minced $0.5 \mathrm{~g}$ portions of frozen endometrium to $4 \mathrm{ml}$ of ice-cold buffer containing $20 \mathrm{mmol} \mathrm{HEPES} / \mathrm{l}, 5 \mathrm{mmol} \mathrm{MgCl}_{2} / 1$, $120 \mathrm{mmol} \mathrm{KCl} / 1,7 \mathrm{mmol}$ dithiothreitol/l and $10 \%$ glycerol $(\mathrm{pH} 7 \cdot 5$ ). Samples were homogenized with a polytron homogenizer for $15 \mathrm{~s}$. After homogenization, an additional $4 \mathrm{ml}$ of buffer containing $1 \%$ Nonidet P-40 was added. The suspension was mixed and subjected to one freeze-thaw cycle. Supernatant obtained after centrifugation at $12000 \times g$ for $5 \mathrm{~min}$ was used to assay the enzyme which catalyses conversion of $\left[{ }^{14} \mathrm{C}\right] \mathrm{ATP}$ to $\left[{ }^{14} \mathrm{C}\right] 2^{\prime}, 5^{\prime}$ oligoadenylate products (Short \& Fulton, 1987).

Activity of $2^{\prime}, 5^{\prime}$-A synthetase in endometrium collected during the second breeding season in Expt 4 was quantified after further modification of the assay. Nonidet $(0.5 \%, \mathrm{v} / \mathrm{v})$ was included in the homogenizing buffer and samples $(2.5 \mathrm{ml}$ homogenizing buffer and $250 \mu \mathrm{g}$ tissue) were homogenized at a power setting of 40 for $40 \mathrm{~s}$ using a Virtishear homogenizer (The Virtis Co., Inc., Gardiner, NY, USA) with a microfine generator. Filter paper discs (Whatman 1) were placed on top of columns of Dowex-1 (Sigma Chemical Co., St Louis, MO, USA) used to separate nucleotide from nucleosides. After application of samples, columns were eluted with three 1 -ml portions of water and two $1-\mathrm{ml}$ portions of $0.01 \mathrm{M}-\mathrm{HCl}: 1 \mathrm{M}-\mathrm{NaCl}$. Radioactivity of each eluate was measured, and counts were normalized to $30000 \mathrm{dpm}$ per assay vessel.

For each endometrial sample, duplicate determinations were performed in each of two different assays. Intra- and interassay coefficients of variation for samples from ewes in Expts 1-3 and the first season of Expt 4 were 10.3\% and $16.9 \%$, respectively. Intra- and interassay coefficients of variation for samples from ewes during the second season of Expt 4 were $13.3 \%$ and $16.1 \%$, respectively. Concentration of protein in the supernatant assayed was determined (Lowry et al., 1951) and activity of 2',5'-A synthetase was expressed as nmol of 2',5'-A produced/mg protein/h.

Statistical analyses. Data were subjected to least-squares analysis of variance (ANOVA) using the General Linear Models procedure of the Statistical Analysis System (SAS, 1982). For Expt 1, ANOVA for a randomized block design was performed for a $2 \times 2$ factorial arrangement. Reproductive status and uterine horn were main effects and season was the block effect. Reproductive status and uterine horn were confounded because endometrium was collected from only the ipsilateral horn of cyclic ewes, but from both horns of pregnant ewes. For Expts 2 and 3, one-way aNOVA was performed for a randomized block design with protein treatment as the main effect and ewe as the block effect. Data from Expts 2 and 3 were then combined (Snedecor \& Cochran, 1980) and a two-way ANOVA was performed; protein treatment and experiment were main effects and the ewe was nested within experiment. For Expt 4, ANOVA was performed for a randomized block design with treatment as the main effect and season as the block effect. All tests of hypotheses were made using the appropriate error terms according to the expectations of the mean squares (Snedecor \& Cochran, 1980).

\section{Results}

\section{Experiment 1}

Mean activity of $2^{\prime}, 5^{\prime}$-A synthetase in endometrium collected on Day 16 from the uterine horn ipsilateral to the corpus luteum was $132 \%$ greater $(P<0.001)$ for pregnant ewes than for cyclic ewes (Table 1). Activity of $2^{\prime}, 5^{\prime}$-A synthetase did not differ between endometrium collected from the ipsilateral and contralateral uterine horns of pregnant ewes.

\section{Experiments 2 and 3}

For ovariectomized ewes in Expt 2, mean activity of $2^{\prime}, 5^{\prime}$-A synthetase in endometrium collected on Day 13 from the uterine horn infused with oTP-1 tended to be greater $(P<0 \cdot 10)$ than in endometrium from the SP-infused uterine horn (Table 2). For intact ewes in Expt 3, mean activity of $2^{\prime}, 5^{\prime}$-A synthetase in endometrium collected on Day 15 from the uterine horn infused with oTP-1 was greater than in endometrium from the SP-infused uterine horn (Table 2), but this 
Table 1. Activity of $2^{\prime}, 5^{\prime}$-oligoadenylate synthetase $(\mathrm{nmol} / \mathrm{mg}$ protein $/ \mathrm{h})$ in endometrium from cyclic and pregnant ewes on Day 16 after oestrus (Expt 1)

\begin{tabular}{lcc}
\hline & Cyclic & Pregnant \\
\hline Ipsilateral horn & $58.5 \pm 9.9^{\mathrm{a}}$ & $135 \cdot 5 \pm 17 \cdot 2^{\mathrm{b}}$ \\
Contralateral horn & - & $119.5 \pm 17 \cdot 2^{\mathrm{b}}$ \\
\hline
\end{tabular}

a,b Mean activity was greater $(P<0.001)$ for pregnant than for cyclic ewes but did not differ between horns of pregnant ewes.

effect was not statistically significant because variation was large and degrees of freedom were few. Across both experiments, intrauterine infusion of oTP-1 increased $(P<0.05)$ activity of $2^{\prime}, 5^{\prime}-\mathrm{A}$ synthetase in endometrium compared with infusion of SP (Table 2).

Table 2. Mean activity of $2^{\prime}, 5^{\prime}$-oligoadenylate synthetase (nmol/mg protein/h) in endometrium from ewes infused with serum protein (SP) or ovine trophoblast protein-l (oTP-1) (Expts 2 and 3)

\begin{tabular}{lcccc}
\hline & SP & oTP-1 & \% increase & Significance \\
\hline $\begin{array}{l}\text { Ovariectomized } \\
\text { ewes }\end{array}$ & $48.8 \pm 2.2$ & $57.7 \pm 2 \cdot 2$ & 18 & $P<0.10$ \\
$\quad \begin{array}{l}\text { (Expt 2) } \\
\text { Intact ewes } \\
\quad(\text { Expt 3) }\end{array}$ & $38.2 \pm 3 \cdot 7$ & $46.5 \pm 3 \cdot 7$ & 22 & n.s. \\
$\begin{array}{c}\text { All ewes } \\
\text { (Expts 2 and 3) }\end{array}$ & $43.5 \pm 2.1$ & $52.1 \pm 2 \cdot 1$ & 20 & $P<0.05$ \\
\hline
\end{tabular}

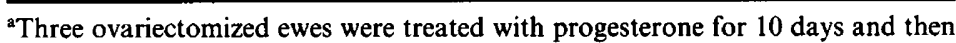
with oestradiol for 2 days. SP was infused into one uterine horn and oTP-1 was infused into the other uterine horn of each ewe on the last 3 days of steroid treatment. Endometrium was collected at hysterectomy on the day after the last infusions.

'Three intact ewes received infusions of SP into one uterine horn and oTP-1 into the other uterine horn on Days 12,13 and 14 after oestrus. Endometrium was collected at hysterectomy on Day 15.

\section{Experiment 4}

Mean activity of $2^{\prime}, 5^{\prime}-A$ synthetase in endometrium collected on Day 16 was greater $(P<0.001)$ for ewes injected with rbIFN- $\alpha_{1} 1$ than for placebo-injected ewes across both years (Table 3). For both treatment groups, greater $(P<0.001) 2^{\prime}, 5^{\prime}$-A synthetase activity was detected in endometrium collected during the second season than in the first season. This probably resulted primarily from modifications to the $2^{\prime}, 5^{\prime}$-A synthetase assay. However, ewes treated with rbIFN- $\alpha_{1} 1$ had a greater increase in endometrial $2^{\prime}, 5^{\prime}$-A synthetase activity than placebo-treated ewes during the second season than during the first, resulting in a treatment $\times$ season interaction $(P<0.001)$.

\section{Discussion}

The results of the present study indicate that activity of $2^{\prime}, 5^{\prime}-\mathrm{A}$ synthetase in endometrium increased during the peri-implantation period of pregnancy in sheep in association with secretion of 
Table 3. Mean activity of $2^{\prime}, 5^{\prime}$-oligoadenylate synthetase $(\mathrm{nmol} / \mathrm{mg}$ protein $/ \mathrm{h})$ in endometrium from cyclic ewes ${ }^{a}$ treated with placebo or recombinant bovine interferon- $\alpha_{1} 1\left(\right.$ rbIFN- $\left.\alpha_{1} 1\right)($ Expt 4)

\begin{tabular}{lrr}
\hline Breeding season & Placebo $^{\text {b }}$ & rbIFN $^{\text {b }}$ \\
\hline 1 & 79.9 & 115.3 \\
2 & 244.4 & 1872.4 \\
\hline
\end{tabular}

${ }^{a}$ Mean activity was affected by treatment $(P<0.001)$, season $(P<0.001)$ and treatment $\times$ season $(P<0.001)$; s.e.m. $=121.5$.

${ }^{b}$ Ewes received i.m. injections of placebo or $1 \mathrm{mg}$ rbIFN$\alpha_{1}-1$ twice a day on Days $12,13,14$ and 15 after oestrus and endometrium was collected at hysterectomy on Day 16.

oTP-1 and inhibition of luteolysis. In cows, activity of $2^{\prime}, 5^{\prime}-\mathrm{A}$ synthetase in endometrium also increases between Days 15 and 18 of pregnancy (Short $e$ t al., 1991), when maternal recognition of pregnancy occurs (Northey \& French, 1980; Humblot \& Dalla Porta, 1984). Increased activity of $2^{\prime}, 5^{\prime}$-A synthetase in endometrium of ewes and cows during early pregnancy is probably due to the action of the conceptus interferons, oTP-1 and bTP-1, respectively, because interferons are known to stimulate the $2^{\prime}, 5^{\prime}$-A synthetase system (see Taylor \& Grossberg, 1990). Further, intrauterine infusion of oTP-1 increased endometrial activity of $2^{\prime}, 5^{\prime}$-A synthetase in the present study, and treatment with bTP-1 in vitro increased activity of $2^{\prime}, 5^{\prime}$-A synthetase in monolayers of cow endometrial stromal and epithelial cells (Short et al., 1991).

Peri-implantation pig conceptuses also secrete proteins which have antiviral activity (Cross \& Roberts, 1989; Groothuis et al., 1990; Mirando et al., 1990a) and are capable of stimulating 2',5'-A synthetase activity in Madin Darby bovine kidney cells and bovine endometrial explants (E. C. Short \& R. D. Geisert, unpublished observations). During early pregnancy, however, these pig conceptus interferons do not stimulate pig endometrial $2^{\prime}, 5^{\prime}$-A synthetase activity (Groothuis et al., 1990; E. C. Short \& R. D. Geisert, unpublished observations) and do not appear to be involved in corpus luteum maintenance in pigs (Harney \& Bazer, 1989). These results suggest that establishment of pregnancy in pigs does not involve increased endometrial $2^{\prime}, 5^{\prime}$-A synthetase activity. Whether increased activity of $2^{\prime}, 5^{\prime}$-A synthetase in endometrium of sheep and cattle is involved in establishment of pregnancy in these species remains to be determined.

Systemic administration of rbIFN to cyclic ewes increases endometrial $2^{\prime}, 5^{\prime}-\mathrm{A}$ synthetase activity (present study), but does not extend inter-oestrous interval in sheep when given on Days $12-15$ at a dose of $2.0 \mathrm{mg} /$ day (Schalue-Francis et al., 1991; M. A. Mirando, M. A. Davis \& F. W. Bazer, unpublished observations) or $2.5 \mathrm{mg} /$ day (Flint et al., 1991). These results suggest that either the $2^{\prime}, 5^{\prime}-\mathrm{A}$ system is not involved in luteolysis or that systemically administered rbIFN- $\alpha_{1} 1$ acts more on different cells (e.g. stromal cells) than does oTP-1 within the uterine lumen (e.g. epithelial cells). In this context, it is noteworthy that treatment with bovine interferons in vitro induces greater $2^{\prime}, 5^{\prime}$-A synthetase activity in stromal cells than in epithelial cells (Short et al., 1991).

The role of the endometrial $2^{\prime}, 5^{\prime}$-A system in preventing CL regression during early pregnancy in ruminants is not known. An intracellular $2^{\prime}, 5^{\prime}$-A-dependent endoribonuclease is involved in cleaving viral and cellular RNAs, thereby preventing synthesis of proteins required for replication of viruses within host cells as well as cellular proteins (see Johnston \& Torrence, 1984; Taylor \& Grossberg, 1990). Increased endometrial activity of $2^{\prime}, 5^{\prime}$-A synthetase induced in sheep and cattle by conceptus interferons during early pregnancy may be involved in the transition of endometrial protein synthesis from that of the oestrous cycle to that of early pregnancy (Findlay et al., 1981) via alteration in degradation of mRNA. OTP-1 induces alterations in endometrial protein synthesis (Godkin et al., 1984; Vallet et al., 1987; Salamonsen et al., 1988) and prevents CL regression 
by inhibiting oxytocin-induced endometrial phosphoinositide hydrolysis and prostaglandin F-2 $\alpha$ secretion (Vallet et al., 1988; Mirando et al., 1990b). It is possible that changes in endometrial protein synthesis are required during early pregnancy in ruminants to reduce oxytocin-induced prostaglandin F-2 $\alpha$ secretion and prevent luteolysis.

Intrauterine infusion of oTP- 1 increases endometrial $2^{\prime}, 5^{\prime}$-A synthetase activity (present study), providing additional evidence that oTP-1 is an interferon; oTP-1 has extensive amino acid sequence homology with several known $\alpha$-interferons as well as the biological activities characteristic of interferons (see Introduction).

Endometrial 2',5'-A synthetase activity is increased more during pregnancy than the increase caused by intrauterine infusion of oTP-1. This may be due to the constant exposure of endometrium to oTP-1 during pregnancy, whereas infusion of oTP-1 $\sim 13-14 \mathrm{~h}$ prior to hysterectomy is unlikely to provide continued stimulation of the endometrium during that entire period. Day 15-16 sheep conceptuses are capable of secreting $>100 \mu \mathrm{g}$ oTP-1/day in culture (Godkin et al., 1982; Ashworth \& Bazer, 1989), which may be indicative of synthesis in vivo, but only $60 \mu \mathrm{g}$ oTP-1 was infused on each day during the present study. Alternatively, conceptus secretory products other than oTP-1 may also increase endometrial $2^{\prime}, 5^{\prime}$-A synthetase activity during early pregnancy in sheep.

Activity of $2^{\prime}, 5^{\prime}$-A synthetase in endometrium of pregnant ewes did not differ between the uterine horns ipsilateral and contralateral to the corpus luteum. This is in contrast to results from cows which indicated that $2^{\prime}, 5^{\prime}$-A synthetase increased between Days 15 and 18 of pregnancy in endometrium from the ipsilateral horn, but was not increased in endometrium from the contralateral horn (Short et al., 1991). Increased endometrial 2',5'-A synthetase activity in both uterine horns of pregnant ewes may be due to elongation of conceptuses into the contralateral uterine horn by Day 16 (Chang \& Rowson, 1965) and apparent secretion of adequate oTP-1 into that uterine horn to stimulate $2^{\prime}, 5^{\prime}$-A synthetase activity. In cows, few conceptuses elongate into the contralateral uterine horn by Day 18 (Chang, 1952; Geisert et al., 1988; Short et al., 1991; see Bazer \& First, 1983). Therefore, sufficient bTP-1 may not have been secreted into the contralateral horn to increase endometrial 2',5'-A synthetase activity significantly (Short et al., 1991).

The reason for the presence of $2^{\prime}, 5^{\prime}-A$ synthetase activity in endometrium of cyclic ewes is not known, but its presence is not unusual, because $2^{\prime}, 5^{\prime}$-A synthetase activity was also detected in endometrium of cyclic cows (Short et al., 1991) and in a variety of cells and tissues which were not challenged with virus, double-stranded RNA or interferon (Hearl \& Johnston, 1985; Laurence et al., 1985; Short et al., 1991). Endometrial 2',5'-A synthetase activity in cyclic ewes and cows may be induced by circulating interferons detected in blood from the uterine artery of cyclic ewes (M. A. Mirando \& F. W. Bazer, unpublished observations) and cyclic gilts (Mirando et al., 1990a).

The mechanism whereby systemic administration of $\operatorname{rbIFN}-\alpha_{1} 1$ enhanced fertility rates in previous studies (Davis et al., 1990; Nephew et al., 1990; Schalue-Francis et al., 1991) is not known, but it does not appear to be identical to that by which oTP-1, secreted by the conceptus or infused in to the uterus, inhibits corpus luteum regression, because systemic administration of rbIFN- $\alpha_{1} 1$ to cyclic ewes does not extend interoestrous intervals (Flint et al., 1991; Schalue-Francis et al., 1991; M. A. Mirando, M. A. Davis \& F. W. Bazer, unpublished observations) or result in detectable antiviral activity within the uterine lumen (Schalue-Francis et al., 1991) when given on Days $12-15$ and at a dose (2.0-2.5 mg/day) which increased fertility in ewes (Davis et al., 1990; Nephew et al., 1990; Schalue-Francis et al., 1991). Alternative mechanisms for increased fertility in ewes treated with $\operatorname{rbIFN-} \alpha_{1} 1$ include (i) inhibition of luteolysis indirectly by acting on follicular development or directly by acting on the corpus luteum; (ii) increased conceptus development and/ or OTP-1 secretion; or (iii) enhanced action of conceptus-secreted oTP-1 on the endometrium. The mechanism does not appear to involve stimulation of conceptus secretion of oTP-1 (Davis et al., 1990). Systemic administration of $\operatorname{rbIFN}-\alpha_{1} 1$ may enhance the antiluteolytic action of oTP- 1 because interoestrous intervals are increased (Nephew et al., 1990; Davis et al., 1990), and plasma 
progesterone concentrations are maintained (M. A. Davis \& F. W. Bazer, unpublished observations) in bred-nonpregnant rbIFN- $\alpha_{1} 1$-treated ewes, but not in bred-nonpregnant placebotreated ewes. Systemic administration of rbIFN- $\alpha_{1} 1$ did extend interoestrous intervals and maintain concentrations of progesterone in plasma of cyclic cows (Plante et al., 1989). The reason for the apparent antiluteolytic effect of rbIFN- $\alpha_{1} l$ in cows is not known, but may be related to the degree of sequence homology, which may be slightly greater with bTP-1 than with oTP-1 (Stewart et al., 1990; Flint et al., 1991). However, administration of $2.5 \mathrm{mg}$ rbIFN- $\alpha_{1} 1 /$ day to cyclic ewes on Days $9-15$ extended interoestrous intervals by $\sim 1 \cdot 5$ days (Flint $e t$ al., 1991).

Results of the present study indicate the activity of $2^{\prime}, 5^{\prime}$-A synthetase in endometrium of ewes is increased during early pregnancy and by intrauterine infusion of oTP-1. These results also indicate that systemic administration of rbIFN- $\alpha_{1} l$ to ewes stimulates endometrial $2^{\prime}, 5^{\prime}-\mathrm{A}$ synthetase activity. Whether increased endometrial $2^{\prime}, 5^{\prime}$-A synthetase activity is involved in establishment of pregnancy in sheep remains to be determined.

This manuscript is published as University of Florida, Agricultural Experiment Station Journal Series No. R-01560. This research was supported by NIH Grant HD 10463, OCAST Grant 3922 and USDA Grant 87-CRCR-1-2502.

\section{References}

Ashworth, C.J. \& Bazer, F.W. (1989) Changes in ovine conceptus and endometrial function following asynchronous embryo transfer or administration of progesterone. Biol. Reprod. 40, 425-433.

Bazer, F.W. \& First, N.L. (1983) Pregnancy and parturition. J. Anim. Sci. 57 (Suppl. 1), 425-460.

Bazer, F.W., Vallet, J.L., Harney, J.P., Gross, T.S. \& Thatcher, W.W. (1989) Comparative aspects of maternal recognition of pregnancy between sheep and pigs. J. Reprod. Fert. Suppl. 37, 85-89.

Bazer, F.W., Thatcher, W.W., Hansen, P.J., Mirando, M.A., Ott, T.L. \& Plante, C. (1991) Physiological mechanisms of pregnancy recognition in ruminants. J. Reprod. Fert. Suppl. 43, 39-47.

Chang, M.C. (1952) Development of bovine blastocyst with a note on implantation. Anat. Rec. 113, $143-161$.

Chang, M.C. \& Rowson, L.E.A. (1965) Fertilization and early embryo development of Dorset horn sheep in the spring and summer. Anat. Rec. 152, 303-316.

Charlier, M., Hue, D., Martal, J. \& Gaye, P. (1989) Cloning and expression of cDNA encoding ovine trophoblastin: its identity with a class-II alpha interferon. Gene 77, 341-348.

Charpigny, G., Reinaud, P., Huet, J.C., Guillomot, M., Charlier, M., Pernollet, J.C. \& Martal, J. (1988) High homology between trophoblastic protein (trophoblastin) isolated from ovine embryo and $\alpha$ interferons. Fed. Europ. Biochem. Soc. 228, 12-16.

Cross, J.C. \& Roberts, R.M. (1989) Porcine conceptuses secrete an interferon during the preattachment period of early pregnancy. Biol. Reprod. 40, 1109-1118.

Davis, M.A., Ott, T.L. \& Mirando, M.A. (1990) Intramuscular administration of recombinant bovine interferon alpha ( $\mathrm{RbIFN}_{\alpha}$ ) increases fertility in ewes without enhancing ovine trophoblast protein-1 production by the conceptus. Biol. Reprod 42 (Suppl. I), 44, Abstr.
Fillion, C., Chaouat, G., Reinaud, P., Charpigny, J.C. \& Martal, J. (1991) Immunoregulatory effects of ovine trophoblastin protein (OTP): all five isoforms suppress PHA-induced lymphocyte proliferation. $J$. Reprod. Immunol. 19, 237-249.

Fincher, K.B., Bazer, F.W., Hansen, P.J., Thatcher, W.W. \& Roberts, R.M. (1986) Proteins secreted by the sheep conceptus suppress induction of uterine prostaglandin $\mathrm{F}-2 \alpha$ release by oestradiol and oxytocin. J. Reprod. Fert. 76, 425-533.

Findlay, J.K., Ackland, N., Burton, R.D., Davis, A.J., Walker, F.M.M., Walters, D.E. \& Heap, R.B. (1981) Protein, prostaglandin and steroid synthesis in caruncular and intercaruncular endometrium of sheep before implantation. J. Reprod. Fert. 62, 361-377.

Flint, A.P.F., Parkinson, T.J., Stewart, H.J., Vallet, J.L. \& Lamming, G.E. (1991). Molecular biology of trophoblast interferons and studies of their effects in vivo. J. Reprod. Fert. Suppl. 43, 13-25.

Geisert, R.D., Zavy, M.T., Biggers, B.G., Garret, J.E. \& Wettemann, R.P. (1988) Characterization of the uterine environment during early conceptus expansion in the bovine. Anim. Reprod. Sci. 16, 11-25.

Godkin, J.D., Bazer, F.W., Moffat, R.J., Sessions, F. \& Roberts, R.M. (1982) Purification and properties of a major, low molecular weight protein released by the trophoblast of sheep blastocysts at day 13-21. J. Reprod. Fert. 65, 141-150.

Godkin, J.D., Bazer, F.W. \& Roberts, R.M. (1984) Ovine trophoblast protein-1, an early secreted blastocyst protein, binds specifically to uterine endometrium and effects protein synthesis. Endocrinology 114, $120-130$.

Groothuis, P.G., Geisert, R.D., Short, E.V., Fulton, R.W. \& Zavy, M.T. (1990) Comparison of antiviral and $2^{\prime}, 5^{\prime}$-oligoadenylate synthetase activity during early pregnancy and the estrous cycle in the pig. J. Anim. Sci. 68 (Suppl. 1), 130, Abstr. 
Harney, J.P. \& Bazer, F.W. (1989) Effect of porcine conceptus secretory proteins on interestrous interval and uterine secretion of prostaglandins. Biol. Reprod. 41, 277-284.

Hearl, W.G. \& Johnston, M.I. (1985) Levels of 2',5'oligoadenylates in the tissues of pathogen-free mice. In The 2-5A System, Molecular and Clinical Aspects of the Interferon-regulated Pathway, pp. 19-24. Ed. B. R. G. Williams \& R. H. Silverman. Alan R. Liss, Inc., New York.

Humblot, P. \& Dalla Porta, M.A. (1984) Effect of conceptus removal and intrauterine administration of conceptus tissue in the cow. Reprod. Nutr. Develop. 24, 529-541.

Johnston, M.I. \& Torrence, P.F. (1984) The role of interferon induced proteins, double-stranded RNA and $2^{\prime}, 5^{\prime}$-oligoadenylate in the interferon-mediated inhibition of viral translation. In Interferon, vol. 3: Mechanisms of Production and Action, pp. 190-298. Ed. R. M. Friediam. Elsevier Science Publishers, Amsterdam.

Imakawa, K., Anthony, R.C., Kazemi, M., Marotti, K.R. Polites, H.G. \& Roberts, R.M. (1987) Interferon-like sequence of ovine trophoblast protein secreted by embryonic trophectoderm. Nature, Lond. 330, 377-379.

Imakawa, K., Hansen, T.R., Malathy, P.-V., Anthony, R.V., Polites, H.G., Marotti, K.R. \& Roberts, R.M. (1989) Molecular cloning and characterization of complementary deoxyribonucleic acids corresponding to bovine trophoblast protein-1: a comparison with ovine trophoblast protein-1 and bovine interferon$\alpha_{\text {II }}$. Molec. Endocr. 3, 127-139.

Laurence, L., Trujillo, M., Samuel, D., Kaphan, S., Roux, D., Hovanessian, A., Marti, J. \& Cailla, H. (1985) Immunological approach of intracellular $2^{\prime}, 5^{\prime}$ linked adenyladenosine oligonucleotides. In The 2-5A System, Molecular and Clinical Aspects of the Interferon-regulated Pathway, pp. 11-18. Ed. B. R. G. Williams \& R. H. Silverman. Alan R. Liss, Inc., New York.

Lifsey, B.J., Baumbach, G.A. \& Godkin, J.D. (1989) Isolation, characterization and immunocytochemical localization of bovine trophoblast protein-1. Biol. Reprod. 40, 343-352.

Lowry, O.H., Rosebrough, N.J., Farr, A.L. \& Randal, R.J. (195I) Protein measurement with the folin phenol reagent. J. biol. Chem. 193, $265-275$.

Martal, J., Lacroix, M.-C., Loudes, C., Saunier, M. \& Wintenberger-Torrès, S. (1979) Trophoblastin, an antiluteolytic protein present in early pregnancy in sheep. J. Reprod. Fert. 56, 63-73.

Martal, J., Charpigny, G., Reinaud, P., Huet, J.C., Guillomet, M., Zouari, K., Pernollet, J.C. \& La Bonnardiere, C. (1988) Embryonic signals and corpus luteum: why three isoforms of trophoblastin can be considered as interferon- $\alpha$ of class II? J. Reprod. Fert. Abst Ser. No. 2, Abst 3.

Mirando, M.A., Harney, J.P., Beer, S., Pontzer, C.H., Torres, B.A., Johnson, H.M. \& Bazer, F.W. (1990a) Onset of secretion of proteins with antiviral activity by pig conceptuses. J. Reprod. Fert. 88, 197-206.

Mirando, M.A., Ott, T.L., Harney, J.P. \& Bazer, F.W. (1990b) Ovine trophoblast protein-one inhibits devel- opment of endometrial responsiveness to oxytocin in ewes. Biol. Reprod. 43, 1070-1078.

Nephew, K.P., McLure, K.E., Day, M.L., Xie, S., Roberts, R.M. \& Pope, W.F. (1990) Enhancement of maternal recognition of pregnancy and embryo survival in sheep by treatment with recombinant bovine interferon-alpha 1. J. Anim. Sci. 68, 2766-2770.

Newton, G.R., Vallet, J.L., Hansen, P.J. \& Bazer, F.W. (1989) Inhibition of lymphocyte proliferation by ovine trophoblast protein-1 and a high molecular weight glycoprotein produced by the peri-implantation sheep conceptus. Am. J. Reprod. Immun. 19, 99-107.

Northey, D.L. \& French, L.R. (1980) Effect of early embryo removal and intrauterine infusion of embryonic homogenates on lifespan of the bovine corpus luteum. J. Anim. Sci. 50, 298-302.

Plante, C., Hansen, P.J., Martinod, S., Siegenthaler, B., Thatcher, W.W., Pollard, J.W. \& Leslie, M.V. (1989) Effect of intrauterine and intramuscular administration of recombinant bovine interferon $\alpha_{1}$ on luteal lifespan in cattle. J. Dairy Sci. 72, 1859-1865.

Plante, C., Hansen, P.J., Mirando, M.A., Thatcher, F.W. \& Bazer, F.W. (1990) Development of antibodies for studying conceptus interferons in the cow. J. Reprod. Immunol. 18, 205-223.

Pontzer, C.H., Torres, B.A., Vallet, J.L., Bazer, F.W. \& Johnson, H.M. (1988) Antiviral activity of the pregnancy recognition hormone ovine trophoblast protein-1. Biochem. biophys. Res. Commun. 152, 801-807.

Roberts, R.M., Imakawa, K., Niwano, Y., Kazemi, M., Malathy, P.-V., Hansen, T.R., Glass, A.A. \& Kronenberg, L.H. (1989) Interferon production by the preimplantation sheep embryo. J. Interferon Res. 9, 175-187.

Salamonsen, L.A., Stuchbery, S.J., O'Grady, C.M. Godkin, J.D. \& Findlay, J.K. (1988) Interferon- $\alpha$ mimics effects of ovine trophoblast protein 1 on prostaglandin and protein secretion by ovine endometrial cells in vitro. J. Endocr. 117, R1-R4.

SAS Institute, Inc. (1982) SAS User's Guide: Statistics, 1982 edition. SAS Institute, Inc., Cary, North Carolina.

Schalue-Francis, T.K., Farin, P.W., Cross, J.C., Keisler, D. \& Roberts, R.M. (1991) Effect of injected bovine interferon- $a_{1} I$ on oestrous cycle length and pregnancy success in sheep. J. Reprod. Fert. 91, 347-356.

Short, E.C. \& Fulton, R.W. (1987) Induction and measurement of $2^{\prime}, 5^{\prime}$-oligoadenylate synthetase in Madin-Darby bovine kidney cells and in cattle. $J$. clin. Microbiol. 25, 1735-1740.

Short, E.C., Geisert, R.D., Helmer, S.D., Zavy, M.T. \& Fulton, R.W. (1991) Expression of antiviral activity and induction of $2^{\prime}, 5^{\prime}$-oligoadenylate synthetase by conceptus secretory proteins enriched in bovine trophoblast protein-1. Biol. Reprod. 44, 261-268.

Snedecor, G.W. \& Cochran, W.G. (1980) Statistical Methods. Iowa State University Press, Ames.

Stewart, H.J., McCann, S.H.E., Barker, P.J., Lee, K.E., Lamming, G.E. \& Flint, A.P.F. (1987) Interferon sequence homology and receptor binding activity of ovine trophoblast antiluteolytic protein. J. Endocr. 115, R13-R15. 
Stewart, H.J., McCann, S.H.E., Northrup, A.J., Lamming, G.E. \& Flint, A.P.F. (1989) Sheep antiluteolytic interferon: $\mathrm{CDNA}$ sequence and analysis of mRNA levels. J. molec. Endocr. 2, 65-70.

Stewart, H.J., McCann, S.H.E. \& Flint, A.P.F. (1990) Structure of an interferon- $\alpha 2$ gene expressed in the bovine conceptus early in gestation. J. molec. Endocr. 4, 275-282.

Taylor, J.L. \& Grossberg, S.E. (1990) Recent progress in interferon research: molecular mechanisms of regulation, action, and virus circumvention. Virus Res. 15, 1-26.

Thatcher, W.W., Hansen, P.J., Gross, T.S., Helmer, S.D., Plante, C. \& Bazer, F.W. (1989) Antiluteolytic effects of bovine trophoblast protein-1. J. Reprod. Fert. Suppl. 37, 91-99.

Thatcher, W.W., Hansen, P.J., Plante, C., Badinga, L., Van Cleeff, J., Danet-Desnoyers, G., Savio, J.D.,
Mirando, M.A. \& Bazer, F.W. (1990) Understanding and exploiting the physiology and endocrinology of reproduction to enhance reproductive efficiency in cattle. Proc. N.Z. Soc. Anim. Prod. 50, 109-121.

Vallet, J.L., Bazer, F.W. \& Roberts, R.M. (1987) The effects of ovine trophoblast protein-one on endometrial protein secretion and cyclic nucleotide. Biol. Reprod. 37, 1307-1316.

Vallet, J.L., Bazer, F.W., Fliss, M.F.V. \& Thatcher, W.W. (1988) Effect of ovine conceptus secretory proteins and purified ovine trophoblast protein-1 on interoestrous interval and plasma concentrations of prostaglandins $\mathrm{F}-2 \alpha$ and $\mathrm{E}$ and 13,14-dihydro-15ketoprostaglandin F-2 $\alpha$ in cyclic ewes. $J$. Reprod. Fert. 84, 493-504.

Received 20 February 1991 